УДК 616-053.32:618.396

DOI 10.11603/24116-4944.2020.1.11479

\author{
๑I. М. Сарапук ${ }^{1}$, Г. А. Павлишин ${ }^{1}$, М.-К. Боршевска-Корнацка ${ }^{2}$, О. В. Кліщ ${ }^{1}$ \\ ${ }^{1}$ Тернопільсъкий нащіональний медичний університет ілені І. Я. Горбачевсъкозо \\ МОЗ України \\ ${ }^{2}$ Варшавський медичний університет

\section{ПРОБЛЕМИ ВИХОДЖУВАННЯ ПЕРЕДЧАСНО НАРОДЖЕНИХ НЕМОВЛЯТ ТА МОЖЛИВОСТІ ЇХ ВИРІШЕННЯ}

Мета дослідження - провести порівняльний аналіз показників виживання та захворюваності передчасно народжених немовлят (дуже та екстремально недоношених) у перинатальних центрах різних країн.

Матеріали та методи. Ретроспективна оцінка стандартизованих перинатальних та неонатальних даних передчасно народжених немовлят з гестаційним віком від 24+0 до 31+6 тижнів, які народилися у перинатальних центрах Тернополя та Варшави. Проведено порівняльний аналіз антенатальних фракторів ризику, особливостей інтранатального періоду, антропометричних показників при народженні дитини, клінічних характеристик у ранньому неонатальному періоді.

Результати дослідження та їх обговорення. Порівняльний аналіз показав, що рівень виживання екстремально недоношених немовлят у Варшавському перинатальному центрі достовірно перевищує показники у регіональному центрі $(p=0,0076)$. Показники захворюваності на сепсис (ранній, пізній), некротичний ентероколіт, внутрішньошлуночкові крововиливи були вищими серед передчасно народжених Тернопільського перинатального центру. Більшість екстремально недоношених та третина дуже недоношених немовлят у регіональному центрі мають постнатальну затримку фізичного розвитку на момент виписування зі стаціонару.

Висновки. Порівняльний аналіз показників виживання та захворюваності серед дуже та екстремально недоношених дітей у Тернопільському та Варшавському перинатальному центрах дозволив 3'ясувати ключові відмінності у підходах до виходжування такої категорії пацієнтів, виокремити перинатальні та неонатальні ризики, пов'язані 3 несприятливим прогнозом, запропонувати можливі шляхи покращання якості надання медичної допомоги.

Ключові слова: передчасно народжені немовлята; екстремально недоношені діти; дуже недоношені діти; рівень виживання; захворюваність; ранні наслідки виходжування.

ПРОБЛЕМЫ ВЫХАЖИВАНИЯ ПРЕЖДЕВРЕМЕННО РОЖДЁННЫХ МЛАДЕНЦЕВ И ВОЗМОЖНОСТИ ИХ РЕШЕНИЯ

Цель исследования - провести сравнительный анализ показателей выживания и заболеваемости недоношенных младенцев (очень и экстремально недоношенных) в перинатальных центрах разных стран.

Материалы и методы. Ретроспективная оценка стандартизированных перинатальных и неонатальных данных недоношенных младенцев с гестационным возрастом от 24+0 до 31+6 недель, которые родились в перинатальных центрах Тернополя и Варшавы. Проведен сравнительный анализ антенатальных факторов риска, особенностей интранатального периода, антропометрических показателей при рождении ребенка, клинических характеристик в раннем неонатальном периоде.

Результаты исследования и их обсуждение. Сравнительный анализ показал, что уровень выживаемости экстремально недоношенных младенцев в Варшавском перинатальном центре достоверно превышает показатели в региональном центре ( $p=0,0076)$. Показатели заболеваемости сепсисом (ранний, поздний), некротическим энтероколитом, внутрижелудочковыми кровоизлияниями были выше среди недоношенных Тернопольского перинатального центра. Большинство экстремально недоношенных и треть очень недоношенных младенцев в региональном центре имеют постнатальную задержку сризического развития на момент выписки из стационара.

Выводы. Сравнительный анализ показателей выживания и заболеваемости среди очень и экстремально недоношенных детей в Тернопольском и Варшавском перинатальных центрах позволил выделить ключевые различия в подходах к выхаживанию такой категории пациентов, перинатальные и неонатальные риски, связанные с неблагоприятным прогнозом, предложить возможные пути улучшения качества оказания медицинской помощи.

Ключевые слова: преждевременно рожденные младенцы; экстремально недоношенные дети; очень недоношенные дети; выживаемость; заболеваемость; ранние последствия выхаживания.

PROBLEMS OF CARING FOR PREMATURE BABIES AND POSSIBILITIES OF THEIR SOLUTION

The aim of the study - to conduct a comparative analysis of survival rates and morbidity of premature infants (very and extremely premature infants) in perinatal centers in different countries.

Materials and Methods. Retrospective evaluation of standardized perinatal and neonatal data of premature infants with gestational age from $24+0$ to $31+6$ weeks, born in the perinatal center of Ternopil and Warsaw. A comparative analysis of antenatal risk factors, features of the intranatal period, anthropometric indicators at childbirth, clinical characteristics in the early neonatal period.

Results and Discussion. Comparative analysis showed that the survival rate of extremely premature infants in the Warsaw Perinatal Center is significantly higher than in the regional center $(p=0.0076)$. The incidence of sepsis (early, late), necrotizing enterocolitis, intraventricular hemorrhage was higher among premature infants of the Ternopil perinatal center. Most extremely premature and one-third of very premature infants in the regional center have a postnatal growth failure at discharge.

Conclusions. Comparative analysis of survival and morbidity rates among very and extremely premature babies in Ternopil and Warsaw perinatal centers revealed key differences in approaches to caring for this category of patients, to identify perinatal and neonatal risks associated with an unfavorable prognosis, to suggest possible ways to improve quality medical care.

Key words: premature infants; extremely premature babies; very premature babies; survival rate; morbidity; early outcomes of nursing. 
Вступ. Передчасні пологи є важливим питанням охорони здоров'я, що викликає велике занепокоєння у всьому світі. У розвинених країнах Європи, США частота передчасних пологів коливається в межах 5-12 \%, може навіть сягати $40 \%$ у менш розвинених регіонах. 3 усіх пологів у світі 11,1 \% є передчасними, а близько $15 \%$ передчасних пологів відбуваються до 32 тижнів гестації $[1,2]$.

3 покращенням якості надання перинатальної допомоги змінились показники виживання передчасно народжених немовлят, зменшились неонатальні втрати. Попри підвищення рівня виживання дуже та екстремально недоношених новонароджених частота неонатальної захворюваності з віддаленими наслідками та ускладненнями, пов'язаними із передчасним народженням, залишається стабільною. Ризик ускладнень збільшується із ступенем незрілості немовляти $[3,4]$.

Важливим питанням щодо покращення результатів виходжування передчасно народжених є освоєння новітніх трендів, міжнародних стандартів та досвіду виходжування таких немовлят у європейських країнах. 3 цією метою була проведена порівняльна оцінка ранніх, короткотривалих наслідків виходжування передчасно народжених немовлят із дуже та екстремально малою масою тіла при народженні в перинатальних центрах різних країн. Порівняльний аналіз показників виживання, захворюваності передчасно народжених немовлят проводили у Тернопільському перинатальному центрі (ТПЦ) та Варшавському перинатальному центрі (ВПЦ), які належать до закладів третинного рівня надання неонатальної допомоги.

МЕТА ДОсЛІДЖЕННЯ - провести порівняльний аналіз показників виживання та захворюваності передчасно народжених немовлят у перинатальних центрах різних країн

МАТЕРІАЛИ ТА МЕТОДИ. Ретроспективно оцінено базу стандартизованих перинатальних та неонатальних даних ТПЦ - 119 передчасно народжених немовлят із гестаційним віком від 24 до 32 тижнів та ВПЦ - 110 передчасно народжених дітей із таким же гестаційним віком.

Проведено аналіз антенатальних фракторів ризику, особливостей інтранатального періоду, антропометричних показників після народження дитини, клінічних характеристик у неонатальному періоді, зокрема наявність дихальних розладів (респіраторний дистрес-синдром, пізніше фрормування бронхолегеневої дисплазії), неврологічних порушень (внутрішньошлуночкові крововиливи, перивентрикулярна лейкомаляція), ретинопатії, інорекційної патології - сепсису, некротичного ентероколіту, тривалість парентерального харчування, показники фрізичного розвитку, постнатальну затримку розвитку у перинатальних центрах двох країн - України (ТПЦ) та Польші (ВПЦ).

Комісією з біоетики Тернопільського національного медичного університету імені І. Я. Горбачевського МО3 України (протокол № 43 від 23.10.2017) порушень морально-етичних норм при проведенні дослідження не виявлено.

Статистичну обробку даних проводили за допомогою «EXCELL FOR WINDOWS» та «STATISTICA 13.0. FOR WINDOWS». Кількісні показники представлено у вигляді медіани (Me) та міжквартильного діапазону (IQR; 25-75 відсотків) залежно від розподілу даних. Для порівняння числових характеристик використовували U-тест МаннаВітні (для двох незалежних груп). Пропорції порівнювали між двома групами за допомогою тесту Сhi-квадрата.

РЕЗУЛЬТАТИ ДОСЛІДЖЕННЯ ТА ЇХ ОБГОВОРЕННЯ.

Демографічні показники, анте- та інтранатальні особливості порівнюваних груп

Впродовж 2016-2017 років у Тернопільському перинатальному центрі народилися 152 дитини із гестаційним віком від 24 до 32 тижнів. У Варшавському перинатальному центрі за період 2014-2016 років народилися 130 немовлят із відповідним гестаційним віком. Серед передчасно народжених немовлят у Тернопільському регіоні було $83(54,6 \%)$ хлопчики і $69(45,4 \%)$ дівчаток. У ВПЦ - 61 (46,9 \%) хлопчик та 69 (53,1 \%) дівчаток без достовірної різниці $(p=0,23)$ між групами порівняння.

Гестаційний вік серед дітей ТПЦ складав - 30,0 [28,0; $31,0]$ тижнів гестації, у ВПЦ - 28,13 22,6 28,0 [26,0; 30,0], $\mathrm{p}<0,001$. Варто відмітити, що у ВПЦ переважали немовлята, народжені до 28 тижнів гестації, - 68 (52,3 \%) (екстремально недоношені діти) порівняно з ТПЦ - 43 $(28,3 \%), p=0,0001$. У Тернопільській групі найбільша частка немовлят народилася у терміні 32 тижні гестації $(p=0,003)$, при цьому у Варшавській групі переважали немовлята 27-ми тижнів гестації $(p=0,006)$ (табл. 1).

Оцінка антенатальних фракторів не виявила суттєвої різниці у патології вагітних серед спостережуваних груп,

Таблиця 1. Розподіл передчасно народжених немовлят за гестаційним віком у Тернопільському та Варшавському перинатальних центрах

\begin{tabular}{||c|c|c|c||}
\hline \multirow{2}{*}{ Гестаційний вік (тижні) } & ТПЦ (n=152) & ВПЦ (n=130) & \multirow{2}{*}{$\mathrm{p}$} \\
\cline { 1 - 3 } & $\mathrm{n}(\%)$ & $\mathrm{n}(\%)$ & 0,596 \\
\hline 22 & $1(0,66)$ & $2(1,54)$ & 0,149 \\
\hline 23 & $2(1,32)$ & $6(4,61)$ & 0,149 \\
\hline 25 & $2(1,32)$ & $6(4,61)$ & 0,791 \\
\hline 26 & $9(5,92)$ & $6(4,61)$ & 0,284 \\
\hline 27 & $10(6,58)$ & $14(10,77)$ & $0,006^{*}$ \\
\hline 28 & $7(4,61)$ & $19(14,61)$ & 0,317 \\
\hline 29 & $12(7,89)$ & $15(11,54)$ & 0,727 \\
\hline 30 & $22(14,47)$ & $16(12,31)$ & 0,863 \\
\hline 31 & $22(14,47)$ & $17(13,08)$ & 0,114 \\
\hline
\end{tabular}

Примітка. * $-p<0,05$. 
зокрема гестоз, еклампсія, гестаційна гіпертензія (23 (15\%) проти 16 (12,3\%), p=0,604), гестаційний діабет (1 (0,65\%) проти $6(4,31 \%), p=0,051)$, захворювання щитоподібної залози (18 (11,84 \%) проти 9 (6,92\%), p=0,223).

Пологи шляхом кесаревого розтину для немовлят менше 32 тижнів гестації у Варшавському центрі складали 69,2 \%, тоді як у ТПЦ - 34,9\%, p<0,001. При цьому суттєвої різниці щодо двійнят (29,6 \% (45 немовлят) i 26,1 \% (34 дитини), p=0,595 відповідно) в обох перинатальних центрах не виявлено.

щодо антропометричних показників, то маса при народженні немовлят у ТПЦ становила 1370,0 [1050,0; $1705,0]$ г, у ВПЦ -1190,0 [850,0; 1480,0] г, p<0,001 (табл. 2).

Оцінка за шкалою Апгар серед немовлят ТПЦ була $7,0[5,0 ; 7,0]$ балів на 1 хвилині і 7,0 [6,0; 7,0] балів на 5 хвилині, в той час у ВПЦ ці показники - $6,0[4,0 ; 7,0]$ і 7,0 $[6,0 ; 7,0]$ балів відповідно, p=0,00027 і p=0,2556. Первинну реанімацію проводили у 44,1\% немовлят Тернопільської групи, тоді як у Варшавській - у 86,9% (p<0,001), при цьому значно більше немовлят у ТПЦ потребували реанімації з інтубацією у пологовій залі порівняно з ВПЦ (56,7\% vs $29.2 \%, p=0,0005)$.

Замісну сурфактантну терапію було проведено 54 (35,5 \%) передчасно народженим дітям у Тернопільському центрі та 85 (65,4 \%) немовлятам у Варшавському $(p<0,001)$. Ентеральне харчування розпочинали в середньому на перший день життя в обох центрах.

Рівень виживання та показники захворюваності серед передчасно народжених немовлят порівнюваних груп

Загальний рівень виживання серед немовлят Тернопільської групи складав 78,29 \% (119 немовлят) порівняно 3 центром у Варшаві - 84,61 \% (110 немовлят), p=0,221. Варто відзначити, що серед екстремально недоношених показники виживання у ТПЦ були нижчими - 48,84\% (21 немовля) порівняно з ВПЦ - 75,0 \% (51 немовля) ( $p=0,0076)$, при цьому без достовірної різниці серед дуже недоношених немовлят в обох центрах - 89,09 \% (98 немовлят) та 95,16 \% (59 немовлят) відповідно ( $p=0,261)$.

Оцінку та аналіз ранніх неонатальних наслідків, показників захворюваності проводили серед тих немовлят, які вижили, відповідно до їх гестаційного віку - екстремально недоношені діти з гестаційним віком менше 28 тижнів і дуже недоношені діти з гестаційним віком 29-32 тижні.

Порівняльна оцінка маси тіла при народженні екстремально недоношених немовлят у Тернопільському та Варшавському центрах (1050,0 [900,0; 1220,0] г та 980,0 [790,0; 1190,0] г відповідно, p=0,4206) та дуже недоношених $(1585,0$ [1320,0; 1800,0] г та 1495,0 [1200,0; 1810,0] г відповідно, $p=0,2802)$ не виявила достовірно статистичної різниці. щодо гестаційного віку, то у ТПЦ та ВПЦ серед екстремально недоношених вік становив $28,0[27,0 ; 28,0]$ і $27,0[26,0 ; 28,0]$ тижнів відповідно, p=0,137; серед дуже недоношених немовлят - 31,0 [30,0; 32,0] та 30,0 [30,0; 31,0] відповідно, p=0,0812. Варто відмітити, що у Тернопільській популяції екстремально недоношені переважали новонароджених із терміном гестації 28 тижнів, тоді як у Варшавській групі - новонароджені з терміном гестації 24-27 тижнів. Щодо групи дуже недоношених, в Тернопільському центрі переважали немовлята 3 терміном гестації 31-32 тижні, у Варшавському центрі - немовлята з гестаційним віком 30-31 тиждень.

Захворюваність та неонатальні наслідки в екстремально та дуже недоношених немовлят на Тернопільщині та у Варшавському центрі представлено в таблиці 3.

Так, в Тернопільському центрі значно менша кількість дуже недоношених немовлят порівняно з Варшавським центром отримувала сурфактантну терапію для лікування респіраторного дистрес-синдрому (РДС) (18,4 \% проти 51,7 \%, p<0,001) та потребувала штучної вентиляції легень (31,6 \% проти 50,0 \%, p<0,05). Щодо екстремально недоношених немовлят, то Тернопільська когорта таких пацієнтів отримувала менше сурфактантної терапії стосовно Варшавської групи (61,9 \% проти 84,3\%, p=0,059), проте інвазивна вентиляційна підтримка проводилась у двох центрах без статистично достовірної різниці (57,1 \% та 74,5\%, p>0,05).

Рівень неінвазивної вентиляційної підтримки в ТПЦ для екстремально недоношених складав 76,2 \% і для дуже недоношених немовлят - $65.3 \%$, тоді як у ВПЦ - 100 і 86,2 \% відповідно, p>0,05 для обох вікових груп. Водночас 17,64 \% екстремально недоношених і 6,9 \% дуже недоношених немовлят у Варшавському центрі мали високочастотну осциляційну вентиляцію (НFО-терапію), і приблизно 3 \% з них - NO-терапію.

3 однаковою частотою в обох центрах спостерігали бронхолегеневу дисплазію (БЛД), ретинопатію, анемію у передчасно народжених немовлят. Відкриту артеріальну протоку (ВАП) частіше діагностували у двох вікових групах Варшавського центру (14,3 \% проти 39,2 \% - в екстремально недоношених, p=0,0523 і 2,0 \% проти 10,3 \% - в дуже недоношених новонароджених, p=0,0526), що свідчить про необхідність поліпшення методів діагностики у Тернопільському центрі.

Ранній сепсис частіше виявляли у дуже недоношених дітей Тернопільського центру (33,7 \%) порівняно з Варшавським $(15,5 \%)$ ( $>0,05)$. У групі екстремально недоношених немовлят частота раннього сепсису статистично не відрізнялась у порівнюваних групах (p=1,000). Разом 3 тим, пізній сепсис в обох групах передчасно народжених

Таблиця 2. Антропометричні параметри при народженні у спостережуваних групах

\begin{tabular}{|l|c|c|c|c||}
\hline \multicolumn{1}{|c|}{ Параметри } & $\begin{array}{c}\text { Статистичні } \\
\text { показники }\end{array}$ & ТПЦ & ВПц \\
\hline $\begin{array}{l}\text { Маса тіла (г) } \\
\text { Маса тіла щодо гестаційного віку } \\
\text { (перцентиль) }\end{array}$ & Me [Lq; Uq] & $1370,0[1050,0 ; 1705,0]$ & $1190,0[850,0 ; 1480,0]$ & $0,0000393^{*}$ \\
\hline $\begin{array}{l}\text { Maca тіла щодо гестаційного віку } \\
\text { (Z-score) }\end{array}$ & Me [Lq; Uq] & $0,36[-0,19 ; 1,08]$ & $0,20[-0,77 ; 0,72]$ & $0,00819^{*}$ \\
\hline Мала маса щодо гестаційного віку & [n (\%)] & $12(7,89)$ & $13(10,0)$ & 0,538 \\
\hline
\end{tabular}

Примітка. * $-p<0,05$. 
Таблиця 3. Захворюваність та неонатальні наслідки в екстремально та дуже недоношених немовлят Тернопільського та Варшавського центрів

\begin{tabular}{|c|c|c|c|c|c|c|}
\hline \multirow{2}{*}{ Показники/неонатальні наслідки } & \multicolumn{3}{|c|}{$\begin{array}{c}\text { Екстремально недоношені немовлята } \\
\text { (гестаційний вік менше } 28 \text { тижнів) }\end{array}$} & \multicolumn{3}{|c|}{$\begin{array}{c}\text { Дуже недоношені немовлята } \\
\text { (гестаційний вік понад } 28 \text { тижнів) }\end{array}$} \\
\hline & $\begin{array}{c}\text { ТПЦ } \\
(n=21)\end{array}$ & \begin{tabular}{|c|} 
ВПЦ \\
$(n=51)$
\end{tabular} & $\mathrm{p}$ & $\begin{array}{c}\text { ТПЦ } \\
(n=98)\end{array}$ & $\begin{array}{c}\text { ВПЦ } \\
(n=58)\end{array}$ & $\mathrm{p}$ \\
\hline Сурфрактант-замісна терапія, n (\%) & $13(61,9)$ & $43(84,3)$ & 0,059 & $18(18,4)$ & $30(51,7)$ & $0,0000^{*}$ \\
\hline Механічна вентиляція, n (\%) & $12(57,1)$ & $38(74,5)$ & 0,1678 & $31(31,6)$ & $29(50,0)$ & $0,0273^{*}$ \\
\hline СРАР-терапія, n( \%) & $16(76,2)$ & $51(100,0)$ & $0,0015^{*}$ & $64(65,3)$ & $50(86,2)$ & $0,0049^{*}$ \\
\hline БЛД, n ( \%) & $11(52,4)$ & $32(62,7)$ & 0,4239 & $6(6,12)$ & $7(12,1)$ & 0,1858 \\
\hline Ранній сепсис, n ( \%) & $5(23,8)$ & $13(25,5)$ & 1,0000 & $33(33,7)$ & $9(15,5)$ & $0,0153^{*}$ \\
\hline Пізній сепсис, n ( \%) & $16(76,2)$ & $18(35,3)$ & $0,0020^{*}$ & $22(22,4)$ & $5(8,6)$ & $0,0297^{*}$ \\
\hline Некротичний ентероколіт, n ( \%) & $1(4,8)$ & $4(7,8)$ & 1,0000 & $21(21,4)$ & $1(1,7)$ & $0,0003^{*}$ \\
\hline ВАП, n (\%) & $3(14,3)$ & $20(39,2)$ & 0,0523 & $2(2,0)$ & $6(10,3)$ & 0,0526 \\
\hline ВШК (I+II ст.) & $12(57,1)$ & $14(27,4)$ & $0,0295^{*}$ & $28(28,6)$ & $9(15,5)$ & 0,0800 \\
\hline ВШК (III-IV ст.) & $2(9,5)$ & $5(9,8)$ & 1,0000 & $2(2,0)$ & $2(3,4)$ & 0,6284 \\
\hline Ретинопатія, n (\%) & $13(61,9)$ & $24(47,1)$ & 0,3052 & $24(24,5)$ & $9(15,5)$ & 0,2259 \\
\hline Анемія, n (\%) & $20(95,2)$ & $47(92,2)$ & 1,0000 & $56(57,1)$ & $43(74,1)$ & 0,0394 \\
\hline $\begin{array}{l}\text { Тривалість парентерального хар- } \\
\text { чування, дні }\end{array}$ & $\begin{array}{l}21,0[13,0 \\
32,0]\end{array}$ & $13,0[9,0 ; 19,0]$ & $0,0046^{*}$ & $13,0[8,0 ; 18,0]$ & $8,0[7,0 ; 13,0]$ & $0,0011^{*}$ \\
\hline Добовий приріст маси, грам & $\begin{array}{c}18,4[16,1 \\
21,3] \\
\end{array}$ & $\begin{array}{c}20,2[16,5 ; \\
23,1] \\
\end{array}$ & 0,3883 & $\begin{array}{c}18,8[15,5 ; \\
22,5] \\
\end{array}$ & \begin{tabular}{|c|}
$18,3[15,9$ \\
$21,6]$ \\
\end{tabular} & 0,9237 \\
\hline $\begin{array}{l}\text { Маса дитини на момент випису- } \\
\text { вання, перцентилі }\end{array}$ & $8,0[4,0 ; 25,0]$ & $20,0[5,0 ; 52,0]$ & 0,1098 & $14,5[5,0 ; 35,0]$ & $18,0[4,0 ; 47,0]$ & 0,3858 \\
\hline $\begin{array}{l}\text { Постнатальна затримка росту на } \\
\text { момент виписування, n (\%) }\end{array}$ & $12(57,1)$ & $15(29,4)$ & $0,0346^{*}$ & $37(37,8)$ & $17(29,3)$ & 0,3020 \\
\hline
\end{tabular}

Примітка. * $-p<0,05$

немовлят Тернопільського центру діагностували частіше порівняно з ВПЦ (76,2 \% проти 35,3 \%, p<0,05 і 22,4 \% проти $8,6 \%, p<0,05)$.

Ще одним із небезпечних захворювань для життя передчасно народженої дитини $є$ некротичний ентероколіт (НЕК), який достовірно частіше спостерігали у немовлят Тернопільського центру порівняно з пацієнтами ВПЦ (21,4 \% проти 1,7\%), p=0,0003.

Тривалість парентерального харчування, як основної причини тривалого використання центральних катетерів, статистично більша в обох вікових групах передчасно народжених ТПЦ порівняно з центром у Варшаві $(p=0,0046$ та $p=0,001)$.

Внутрішньошлуночкові крововиливи (ВШК I-ІІ ст.) діагностовано у 57,1 \% екстремально недоношених дітей Тернопільського центру, що достовірно перевищувало показники у таких же пацієнтів ВПЦ (27,4 \%), p=0,0295, при цьому без значимої різниці щодо частоти ВШК (IIIIV ст.) в порівнюваних центрах.

Варто відзначити, що 95,6 \% передчасно народжених немовлят ВПЦ отримували виключно грудне молоко (материнське, донорське), тоді як у ТПЦ лише 2,5 \% дітей були на грудному вигодовуванні (p<0,001), 19,3 \% - на змішаному годуванні (материнське молоко й адаптована суміш для передчасно народжених), решта - виключно на штучному вигодовуванні (лише суміш).

На момент виписування зі стаціонару в 57,1 \% екстремально недоношених дітей Тернопільського центру спостерігали постнатальну недостатність росту, у Варшавському центрі - у 29,4 \% пацієнтів ( $p=0,0346)$.

Обговорення результатів. На сьогодні є недостатньо інформації щодо порівняльного аналізу виходжування передчасно народжених немовлят, оцінки їх виживання та захворюваності у різних перинатальних центрах, вітчизняних та європейських. Дане дослідження ознайомлює 3 показниками виходжування екстремально та дуже недоношених немовлят у Тернопільському перинатальному центрі (Україна) та Варшавському перинатальному центрі (Польша), спонукає порівняти вітчизняні та міжнародні підходи до виходжування передчасно народжених дітей, 3'ясувати певні відмінності, i, враховуючи їх, покращати кінцеві результати.

Незважаючи на те, що загальний рівень виживання передчасно народжених немовлят із гестаційним віком менше 32 тижнів статистично не відрізнявся у двох центрах, показники виживання серед екстремально недоношених суттєво відрізнялися у Тернопільському та Варшавському центрах (48,84 \% проти 75,0 \%, p=0,0076). Така відмінність у показниках виживання екстремально недоношених немовлят може бути пов'язана з особливостями надання перинатальної допомоги, зокрема проведенням антенатальної стероїдної профрілактики, пренатальної терапії сульфратом магнію для попередження неврологічних ускладнень у немовлят, вибором методу родорозрішення, наданням якісної реанімаційної допомоги та адекватного менеджменту в ранньому неонатальному періоді.

Одним із важливих фракторів, що впливає на виживання передчасно народженої дитини, його ранні та віддалені наслідки, неврологічні порушення, $€$ спосіб родорозрішення [5]. На сьогодні відомо, що кесарів розтин покращує показники виживання екстремально та дуже недоношених немовлят, новонароджених із внутрішньоутробною затримкою розвитку $[6,7]$. У вітчизняному перинатальному центрі пологи шляхом кесаревого роз- 
тину складали 34,9 \%, тоді як у Варшавському центрі - 69,2 \%. Високий показник кесаревого розтину свідчить про активне антенатальне ведення вагітності з високим ризиком [7].

Зважаючи на необхідність первинної реанімації, значна частка немовлят, які потребували реанімаційних заходів у пологовій залі, була інтубована на перших хвилинах життя. Варто відзначити, що використання у пологовій залі інвазивних методик вентиляції порівнянно з неінвазивними збільшує ризик не лише щодо проведення непрямого масажу серця, введення епінесрину [8], але й продовження інвазивної вентиляції з усіма наступними наслідками (розвиток бронхолегеневої дисплазії, неврологічних порушень) [9], ризик нозокоміальної інфекції, зокрема вентиляторасоційованої пневмонії, катетерасоційованих інфрекцій [10]

Нозокоміальні інфеекції залишаються на сьогодні значною проблемою для екстремально і дуже недоношених немовлят, які тривало лікуються у відділеннях інтенсивної терапії. Національний інститут дитячого здоров'я та розвитку людини (The National Institute of Child Health and Human Development) відзначив, що $46 \%$ немовлят із гестаційним віком менше 25 тижнів і $29 \%$ немовлят терміном гестації 25-28 тижнів упродовж перебування у відділеннях інтенсивної терапії зазнають серйозних нозокоміальних інфрекцій [11].

Порівняльний аналіз засвідчив, що прояви пізнього сепсису частіше діагностували у передчасно народжених немовлят Тернопільського центру. Одним із важливих фракторів, що потенційно впливає на ці показники, є особливість виходжування такої категорії пацієнтів. Так, у вітчизняних центрах здебільшого переважають стандартні методи виходжування, які не передбачають залучення батьків у процес виходжування, догляду, на відміну від європейських підходів, зокрема у Варшавському центрі активно застосовується кенгуру-метод із батьками. Контакт шкіра-до-шкіри забезпечує позитивні результати у виходжуванні передчасно народжених немовлят, попереджуючи ризик розвитку гіпотермії, нозокоміальної інфрекції, низку ускладнень, особливо в екстремально та дуже недоношених малюків $[12,13]$. Ще одним важливим чинником, який впливає на розвиток іноекційного процесу, є особливість вигодовування немовлят. Так, у Варшавському центрі немовлят вигодовують грудним молоком (материнське, донорське), тоді як у Тернопільському центрі переважає штучне вигодовування з перших днів життя. Відомо, що грудне молоко завдяки унікальному вмісту антитіл, фрагоцитів, лактофрерину, пробіотиків покращує імунний захист дитини, процеси травлення, запобігаючи розвитку виразково-некротичного ентероколіту та сепсису [14, 15].

Водночас, зважаючи на кращу толерантність грудного молока у передчасно народжених немовлят, повне ентеральне харчування розпочинається швидше, а тому скорочується тривалість парентерального харчування і зменшується ризик розвитку катетерасоційованих інфекцій [16]. Варто зазначити, що тривале парентеральне харчування у передчасно народжених дітей як основна причина використання центральних катетерів, розвитку нозокоміального сепсису достовірно перевищує в обох вікових групах Тернопільського центру порівняно з Варшавським $(p=0,0046, p=0,001)$.

щодо НЕКу, переважання його у дуже недоношених Тернопільського центру порівняно з Варшавським під- тверджує поєднання кількох несприятливих фракторів у цій групі, зокрема низької оцінки за Апгар, особливостей вигодовування та догляду, несвоєчасної діагностики ВАПу [17]. За даними літератури, тривале парентеральне харчування, раннє штучне вигодовування асоціюються з підвищеним ризиком розвитку НЕКу [18]. Відомо, що грудне вигодовування відіграє протективну роль щодо розвитку сепсису, НЕКу, що є необхідною складовою виходжування немовлят Тернопільської групи, оскільки тільки у 2,5 \% випадків спостерігається вигодовування грудним молоком $[13,18]$. Водночас, за результатами дослідження Epipage-2, своєчасна діагностика ВАПу, ранній скринінг, ехокардіографрія у передчасно народжених попереджують неонатальну смертність у цієї категорії пацієнтів [19].

Внутрішньошлуночкові крововиливи (ВШК) $є$ частою патологією у недоношених немовлят, частота ВШК I-II ступенів - близько 11 \%, тяжкі ВШК (III-IV ступінь) зустрічаються у 3-5\% передчасно народжених немовлят [20]. Щодо вікової категорії немовлят менше 32 тижнів гестації, то ВШК спостерігаються до 20 \%, у новонароджених менше 1500 г частота ВШК I-IV ступенів складає до 27 \% випадків [21].

Аналіз захворюваності у Тернопільському центрі свідчить, що понад 50 \% екстремально недоношених та третина дуже недоношених немовлят мали ультразвукові ознаки ВШК I-II ступенів, перевищуючи показники серед немовлят Варшавського центру. Серед основних чинників, з якими пов'язано виникнення ВШК у передчасно народжених, є низький відсоток антенатальної стероїдної терапії [22], транспортування передчасно народженої дитини до лікарні вищого рівня [23], вагінальні пологи [23, 24], респіраторний дистрес із епізодами гіпокапнії, гіперкапнія, гіпоксія, ацидемія [25, 26], нестабільність артеріального тиску, коливання мозкового кровотоку, підвищення центрального венозного тиску [27], на що слід звернути увагу регіональній акушерсько-неонатологічній службі. Втім, для нормалізації нестабільності мозкового кровотоку доцільно активно впроваджувати кенгурування, що, за даними літератури, покращує мозковий кровотік у цієї категорії пацієнтів [28].

Незважаючи на досягнення у виходжуванні передчасно народжених, захворюваність на БЛД не знижується, що призводить до тривалої госпіталізації, високих витрат на лікування, розвитку хронічного легеневого захворювання 3 несприятливими неврологічними наслідками [29, 30]. Так, за даними Американської академії педіатрії, середній показник захворюваності на БЛД серед немовлят із масою до 1500 г становить $23 \%$ [31]. У передчасно народжених до 29 тижнів гестації показник розвитку БЛД складає 40 \%, у групі немовлят із масою менше 1000 г частота БЛД зростає до $35 \%$ [32].

3 метою попередження розвитку БЛД, за сучасними рекомендаціями, необхідна ініціація реанімації у пологовій залі з мінімальним киснем $\mathrm{FiO}_{2}(0,3-0,4)$ із використанням Т-системи для забезпечення постійного позитивного тиску в дихальних шляхах (СРАР) чи неінвазивної переривчастої вентиляції з позитивним тиском (NIPPV), із застосуванням пульсоксиметрії для уникнення високих концентрацій кисню, якомога рання екстубація, а також забезпечення адекватного харчування як парентерального, так і ентерального, з перевагою грудного вигодовування [33-35].

Харчування передчасно народжених немовлят впливає не лише на захворюваність, але й на їх фрізичний 
розвиток. Ця категорія дітей в умовах позаутробного життя для досягнення відповідних параметрів фрізичного розвитку повинна збільшити свою масу тіла у кілька разів до досягнення повного гестаційного терміну. Постійний моніторинг показників фрізичного розвитку немовлят від народження вважається добрим предиктором клінічного та нутритивного статусу дитини, показником ефективності лікування [36].

Значна частка передчасно народжених у Тернопільському центрі - 57,1 \% надзвичайно недоношених дітей та 37,8 \% немовлят із дуже малою масою тіла мали невідповідні маси тіла на момент виписування зі стаціонару - менше <10-го перцентиля для віку та статі. Практично половина із них мала масу тіла, нижчу 3-го перцентиля (41,67 та 48,65 \% відповідно), що свідчить про недостатній фрізичний розвиток цієї категорії пацієнтів під час лікування та виходжування. Основні проблеми, які призводять до затримки постнатального розвитку передчасно народжених, пов'язані з особливостями вигодовування в ранньому неонатальному періоді як щодо ентерального харчування (раннє штучне вигодовування із частими проявами інтолерантності, відсутність комплексних збагачувачів при грудному вигодовуванні), так і парентерального (відсутність повноцінних компонентів).

На сьогодні для попередження постнатального порушення розвитку дитини рекомендована методика агресивного харчування, як парентерального, так і ентерального, що зменшує на 23 \% частоту постнатальної затримки фрізичного розвитку [37]. Комітет ESPGHAN рекомендує ентеральну нутритивну саплементацію для дуже недоношених немовлят, що забезпечує адекватне (110-135 ккал/кг/добу) споживання енергії та збільшення маси на 17-20 г/кг на день [38].

Водночас на показники фрізичного розвитку в передчасно народжених немовлят позитивно впливає метод виходжування з кенгуруванням, зокрема збільшуючи їх масу, довжину, окружність голови, а також покращуючи лактацію та показники грудного вигодовування (до
7-100 \%) на момент виписування зі стаціонару чи на період 40-41 тиждень ПМВ [39, 40].

ВИСнОВКИ. 1. Порівняльний аналіз показників виживання та захворюваності серед дуже та екстремально недоношених дітей у Тернопільському та Варшавському перинатальному центрах дозволив показати ключові відмінності у підходах до виходжування такої категорії пацієнтів, виокремити перинатальні та неонатальні ризики, пов'язані з несприятливим прогнозом, з'ясував можливості покращання якості надання медичної допомоги.

2. Оцінка ранніх наслідків виходжування передчасно народжених немовлят виявила, що рівень виживання екстремально недоношених немовлят у Варшавському перинатальному центрі достовірно вищий за показники у регіональному центрі. При цьому захворюваність на сепсис (ранній, пізній), некротичний ентероколіт, внутрішньошлуночкові крововиливи була вищою серед передчасно народжених Тернопільського перинатального центру. Більшість екстремально недоношених та третина дуже недоношених немовлят у регіональному центрі мають постнатальну затримку фрізичного розвитку на момент виписування зі стаціонару.

3. 3 метою покращання клінічних результатів виходжування передчасно народжених варто звернути увагу на якість надання медичної допомоги та впровадження сучасних рекомендацій, нових підходів. Зокрема, для зменшення неврологічних ускладнень у передчасно народжених немовлят менше 32 тижнів гестації рекомендувати розширити показання до кесаревого розтину. В ранньому неонатальному періоді екстремально недоношеним та дуже недоношеним використовувати неінвазивну респіраторну підтримку, широке охоплення СРАР-терапією. Активно впроваджувати грудне вигодовування, сімейноорієнтований догляд за передчасно народженою дитиною, метод кенгуру, що допоможе запобігти несприятливим наслідкам у передчасно народжених немовлят.

ПЕРСПЕКТИВИ ПОДАЛЬШИХ ДОСЛІДЖЕНЬ. ПОдальші дослідження порівняльного характеру дозволять оцінити віддалені, довгострокові результати виходжування передчасно народжених немовлят.

\section{СПИСОК ЛІТЕРАТУРИ}

1. The global epidemiology of preterm birth / J. P. Vogel, S. Chawanpaiboon, A. B. Moller [et al.] // Best. Pract. Res. Clin. Obstet. Gynaecol. - 2018. - Vol. 52. - P. 3-12.

2. March of Dimes, $\mathrm{PMNCH}$, Save the Children, WHO: Born Too Soon: The Global Action Report on Preterm Birth. Geneva, WHO, 2012.

3. Altimier L. The neonatal integrative developmental care model: Advanced clinical applications of the seven core measures for neuroprotective family-centered developmental care / L. Altimier, R. Phillips // Newborn \& Infant Nursing Reviews. - 2016. - Vol. 16. - P. 230-244.

4. Lin Y. C. Growth and neurodevelopmental outcomes of extremely low birth weight infants: a single center's experience / Y. C. Lin, Y. J. Lin, C. H. Lin // Pediatr. Neonatol. - 2011. Vol. 52. - Issue 6. - P. 342-348.

5. Perinatal outcome and long-term follow-up of extremely low birth weight infants depending on the mode of delivery / J. A. Minguez-Milio, J. L. Alcázar, M. Aubá [et al.] // J. Matern. Fetal Neonatal Med. - 2011. - Vol. 24 (10). - P. 1235-1238.

6. LeeH.C. Survival rates and mode of delivery for vertex preterm neonates according to small- or appropriate-for-gestational-age status / H. C. Lee, J. B. Gould // Pediatrics. - 2006. - Vol. 118. P. 1836-1844.

7. Mortality and severe morbidity of very preterm infants: Comparison of two French cohort studies / A. Godeluck, P. Gérardin, V. Lenclume [et al.] // BMC Pediatr. - 2019. Vol. 19. - P. 360.

8. Pulmonary recruitment strategy in preterm neonates $<29$ weeks of gestational age to reduce the need for intubation in the delivery room / F. Petrillo, L. Valenzano, C. Franco [et al.] // Am. J. Perinatol. - 2019. - Vol. 36 (02). - P. 115-119.

9. Non-invasive ventilation in neonatology / J. Behnke, B. Lemyre, C. Czernik [et al.] // Dtsch. Arztebl. Int. - 2019. Vol. 116 (11). - P. 177-183.

10. Ramasethu J. Prevention and treatment of neonatal nosocomial infections / J. Ramasethu // Matern Health Neonatol. Perinatol. - 2017. - Vol. 3. - P. 5.

11. Polin R. A. Nosocomial Infections in the Neonatal Intensive Care Unit / R. A. Polin, L. Saiman // NeoReviews. - 2003. - Vol. 4(3). - P. 81-89. 
12. Understanding kangaroo care and its benefits to preterm infants / M. L. Campbell-Yeo, T. C. Disher, B. L. Benoit, C. C. Johnston // Pediatric Health Med. Ther. - 2015. Vol. 6. - P. 15-32.

13. Casper C. Regular and prolonged skin-to-skin contact improves short-term outcomes for very preterm infants: A dosedependent intervention / C. Casper, I. Sarapuk, H. Pavlyshyn // Archives de Pédiatrie. - 2018. - Vol. 25 (8). - P. 469-475.

14. Impact of early human milk on sepsis and health care costs in very low birth weight infants / A. L. Patel, T. J. Johnson, J. L. Engstrom [et al.] // J. Perinatol. - 2013. - Vol. 33. - P. 514-519.

15. Wight N. E. Breastfeeding the NICU infant: What to expect / N. E. Wight // Clin. Obstet. Gynecol. - 2015. Vol. 58 (4). - P. 840-854.

16. Risk factors for nosocomial infections in neonatal intensive care units (NICU) / C. Nanou, I. Paulopoulou, G. Losis [et al.] // Health Sci. J. - 2015. - Vol. 9. - P. 9.

17. Maffei D. Human milk is the feeding strategy to prevent necrotizing enterocolitis! / D. Maffei, R. J. Schanler // Semin. Perinatol. - 2017. - Vol. 41. - P. 36.

18. Risk factors for necrotizing enterocolitis: A prospective multicenter case-control study / D. J. C. Berkhouta, P. Klaassen, H. J. Niemarktc [et al.] // Neonatology. -2018. - Vol. 114. -P. 277-284.

19. Ancel P. Y. EPIPAGE 2: a preterm birth cohort in France in 2011 / P. Y. Ancel, F. Goffinet, EPIPAGE 2 Writing Group // BMC Pediatr. - 2014. - Vol. 14. - P. 97.

20. Neonatal IVH-mechanisms and management / G. Kenet A. A. Kuperman, T. Strauss, B. Brenner // Thromb. Res. - 2011. - Vol. 127, No. 3. - P. S120.

21. Intraventricular hemorrhage in neonates born before 32 weeks of gestation-retrospective analysis of risk factors / D. Szpecht, M. Szymankiewicz, I. Nowak, J. Gadzinowski // Childs. Nerv. Syst. - 2016. - Vol. 32. - P. 1399-1404.

22. Antenatal steroids and neonatal outcome after chorioamnionitis: a meta-analysis / J. V. Been, P. L. Degraeuwe, B. W. Kramer, L. J. Zimmermann // BJOG. -2011. - Vol. 118. -P. 113

23. Mohamed M. A. Transport of premature infants is associated with increased risk for intraventricular haemorrhage / M. A. Mohamed, H. Aly // ADC Fetal Neonatal Ed. - 2010. Vol. 95. - P. F403.

24. Neurodevelopmental outcomes of infants born at $<29$ weeks of gestation admitted to Canadian neonatal intensive care units based on location of birth / R. Amer, D. Moddemann, M. Seshia [et al.] // J. Pediatr. - 2018. - Vol. 196. - P. 31.

25. Severe intraventricular hemorrhage in extremely premature infants: are high carbon dioxide pressure or fluctuations the culprit? / D. Altaany, G. Natarajan, D. Gupta [et al.] // Am. J. Perinatol. - 2015. - Vol. 32. - P. 839.

26. PaCO2 in surfactant, positive pressure, and oxygenation randomised trial (SUPPORT) / N. Ambalavanan, W. A. Carlo, L. A. Wrage [et al.] // ADC Fetal Neonatal Ed. - 2015. Vol. 100. - P. F145.

\section{REFERENCES}

1. Vogel, J.P., Chawanpaiboon, S., Moller, A.B., Watananirun, K., Bonet, M., \& Lumbiganon, P. (2018). The global epidemiology of preterm birth. Best Pract. Res. Clin. Obstet. Gynaecol., 52, 3-12.

2. (2012). March of Dimes, PMNCH, Save the Children, WHO: Born Too Soon: The Global Action Report on Preterm Birth. Geneva, WHO.

3. Altimier, L., \& Phillips, R. (2016). The neonatal integrative developmental care model:Advanced clinical applications of the seven core measures for neuroprotective family-centered developmental care. Newborn \& Infant Nursing Reviews, 16, 230-244.
27. Early hypoxemia burden is strongly associated with severe intracranial hemorrhage in preterm infants / Z. A. Vesoulis, R. L. Bank, D. Lake [et al.] // J. Perinatol. - 2019. Vol. 39. - P. 48.

28. Impact of kangaroo mother care on cerebral blood flow of preterm infants / A. A. Korraa, A. A. Nagger, R. A. Mohamed, N. M. Helmy // Ital. J. Pediatr. - 2014. - Vol. 40. - P. 83.

29. Davidson L. M. Bronchopulmonary dysplasia: chronic lung disease of infancy and long-term pulmonary outcomes / L. M. Davidson, S. K. Berkelhamer // J. Clin. Med. - 2017. Vol. 6 (1). - pii: E4.

30. Global incidence of bronchopulmonary dysplasia among extremely preterm infants: a systematic literature review / C. Siffel, K. D. Kistler, J. F. M. Lewis, S. P. Sarda // J. Matern. Fetal Neonatal Med. - 2019. - Vol. 9. - P. 1-11.

31. Committee on Fetus and Newborn. American Academy of Pediatrics and Canadian Paediatric Society. Postnatal cotricosteroids to treat or prevent chronic lung disease in preterm infants. Pediatrics. - 2002. - Vol. 109 (2). - P. 330-338.

32. Nelin L. D. How to decrease bronchopulmonary dysplasia in your neonatal intensive care unit today and "tomorrow" / L. D. Nelin, V. Bhandari // F1000Res. - 2017. - Vol. 6. - P. 539.

33. Systematic review and meta-analysis of optimal initial fraction of oxygen levels in the delivery room at $\leq 32$ weeks / O. D. Saugstad, D. Aune, M. Aguar [et al.] // Acta Paediatr. 2014. - Vol. 103 (7). - P. 744-751.

34. Higher or lower oxygen for delivery room resuscitation of preterm infants below 28 completed weeks gestation: a metaanalysis / J. L. Oei, M. Vento, Y. Rabi [et al.] // ADC Fetal Neonatal Ed. - 2017. - Vol. 102 (1). - P. F24-F30.

35. Bubramaniam P. Prophylactic nasal continuous positive airway pressure for preventing morbidity and mortality in very preterm infants / P. Bubramaniam, J. J. Ho, P. G. Davis // Cochrane Database Syst. Rev. - 2016. - No. 6. - P. 1465-1858.

36. Fenton T. R. A Systematic review and meta-analysis to revise the Fenton growth chart for preterm infants / T. R. Fenton, J. H. Kim // BMC Pediatr. - 2013. - Vol. 13. - P. 59.

37. Effect of breastfeeding versus formula milk feeding on preterm infants in the neonatal intensive care unit / Y. W. Li, C. Y. Yan, L. Yang, Z. L. Han // Chin. J. Contemp. Pediatr. 2017. - Vol. 19 (5). - P. 572-575.

38. ESPGHAN/ESPEN/ESPR/CSPEN guidelines on pediatric parenteral nutrition /W. A. Mihatsch, C. Braegger, J. Bronsky [et al.] // Clin. Nutr. - 2018. - Vol. 37, (6 Pt B). - P. 2303-2305.

39. Postnatal growth standards for preterm infants: The preterm postnatal follow-up study of the INTERGROWTH-21(st) project / J. Villar, F. Giuliani, Z. Bhutta [et al.] // Lancet Glob. Health. - 2015. - Vol. 3 (11). - P. 681-691.

40. Risk factors associated with growth failure in the followup of very low birth weight newborns / M. M. Rover, C. S. Viera, R. C. Silveira [et al.] // J. Pediatr. (Rio J). - 2016. - Vol. 92. P. 307-313.

4. Lin, Y.C., Lin, Y.J., \& Lin, C.H. (2011). Growth and neurodevelopmental outcomes of extremely low birth weight infants: a single center's experience. Pediatr. Neonatol, 52, 342-348.

5. Minguez-Milio, J.A., Alcázar, J.L., Aubá, M., RuizZambrana, A., \& Minguez, J. (2011). Perinatal outcome and long-term follow-up of extremely low birth weight infants depending on the mode of delivery. J. Matern. Fetal Neonatal Med., 24 (10), 1235-1238.

6. Lee, H.C., \& Gould, J.B. (2006). Survival rates and mode 
of delivery for vertex preterm neonates according to small- or appropriate-for-gestational-age status. Pediatrics, 118, 1836-1844.

7. Godeluck, A., Gérardin, P., Lenclume, V., Mussard, C., Robillard, P.Y., Sampériz, S., ..., \& Ramful, D. (2019). Mortality and severe morbidity of very preterm infants: comparison of two French cohort studies. BMC Pediatr., 19, 360.

8. Petrillo, F., Valenzano, L., Franco, C., Calò, G., Dentico, D., Manzoni, P., ..., \& Del Vecchio, A. (2019). Pulmonary recruitment strategy in preterm neonates $<29$ weeks of gestational age to reduce the need for intubation in the delivery room. $A m$. J. Perinatol., 36 (02), 115-119.

9. Behnke, J., Lemyre, B., Czernik, C., Zimmer, K.P., Ehrhardt, H., \& Waitz, M. (2019). Non-Invasive Ventilation in Neonatology. Dtsch. Arztebl. Int., 116 (11), 177-183.

10. Ramasethu, J. (2017). Prevention and treatment of neonatal nosocomial infections. Matern. Health Neonatol. Perinatol., 3, 5.

11. Polin, R.A., \& Saiman, L. (2003). Nosocomial infections in the neonatal intensive care unit. NeoReviews, 4 (3), 81-89.

12. Campbell-Yeo, M.L., Disher, T.C., Benoit, B.L., \& Johnston, C.C. (2015). Understanding kangaroo care and its benefits to preterm infants. Pediatric Health Med. Ther., 6, 15-32.

13. Casper, C., Sarapuk, I., \& Pavlyshyn, H. (2018). Regular and prolonged skin-to-skin contact improves short-term outcomes for very preterm infants: A dose-dependent intervention. Archives de Pédiatrie, 25 (8), 469-475.

14. Patel, A.L., Johnson, T.J., Engstrom, J.L., Fogg, L.F., Jegier, B.J., Bigger, H.R., \& Meier, P.P. (2013). Impact of early human milk on sepsis and health care costs in very low birth weight infants. J. Perinatol, 33, 514-519.

15. Wight, N.E. (2015). Breastfeeding the NICU infant: What to expect. Clin. Obstet. Gynecol., 58 (4), 840-854.

16. Nanou, C., Paulopoulou, I., Losis, G., Tsoumakas, K., \& Saroglou, G. (2015). Risk factors for nosocomial infections in neonatal intensive care units (NICU). Health Sci. J., 9, 9.

17. Maffei, D., \& Schanler, R.J. (2017). Human milk is the feeding strategy to prevent necrotizing enterocolitis! Semin. Perinatol., 41, 36.

18. Berkhouta, D.J.C., Klaassen, P., Niemarktc, H.J., de Booded, W.P., Cosseye, V., van Goudoever, G.B., ..., \& de Meij, T.G.J. (2018). Risk factors for necrotizing enterocolitis: A prospective multicenter case-control study. Neonatology, 114, 277-284.

19. Ancel, P.Y., Goffinet, F., \& EPIPAGE 2 Writing Group. (2014). EPIPAGE 2: a preterm birth cohort in France in 2011. BMC Pediatr., 14, 97.

20. Kenet, G., Kuperman, A.A., Strauss, T., \& Brenner, B. (2011). Neonatal IVH--mechanisms and management. Thromb. Res., 127, 3, S120.

21. Szpecht, D., Szymankiewicz, M., Nowak, I., \& Gadzinowski, J. (2016). Intraventricular hemorrhage in neonates born before 32 weeks of gestation-retrospective analysis of risk factors. Childs. Nerv. Syst., 32, 1399-1404.

22. Been, J.V., Degraeuwe, P.L., Kramer, B.W., \& Zimmermann, L.J. (2011). Antenatal steroids and neonatal outcome after chorioamnionitis: a meta-analysis. BJOG, 118, 113.

23. Mohamed, M.A., \& Aly, H. (2010). Transport of premature infants is associated with increased risk for intraventricular haemorrhage. ADC Fetal Neonatal Ed., 95, F403.

24. Amer, R., Moddemann, D., Seshia, M., Alvaro, R.E., Lee, A.S.K., ..., \& Shah, P. (2018). Neurodevelopmental outcomes of infants born at $<29$ weeks of gestation admitted to Canadian neonatal intensive care units based on location of birth. J. Pediatr., 196, 31.

25. Altaany, D., Natarajan, G., Gupta, D., Zidan, M., \& Chawla. S. (2015). Severe intraventricular hemorrhage in extremely premature infants: are high carbon dioxide pressure or fluctuations the culprit? Am. J. Perinatol., 32, 839

26. Ambalavanan, N., Carlo, W.A., Wrage, L.A., Das, A., Laughon, M., Cotton, C.M., ..., \& Higgins, R.D. (2015). PaCO2 in surfactant, positive pressure, and oxygenation randomised trial (SUPPORT). ADC Fetal Neonatal Ed., 100, F145.

27. Vesoulis, Z.A., Bank, R.L., Lake, D., Wallman-Stokes, A., Sahni, R., Moorman, J.R., ..., \& Mathur, A.M. (2019). Early hypoxemia burden is strongly associated with severe intracranial hemorrhage in preterm infants. J. Perinatol., 39, 48.

28. Korraa, A.A., Nagger, A.A., Mohamed, R.A., \& Helmy, N.M. (2014). Impact of kangaroo mother care on cerebral blood flow of preterm infants. Ital. J. Pediatr., 40, 83.

29. Davidson, L.M., \& Berkelhamer, S.K. (2017). Bronchopulmonary dysplasia: chronic lung disease of infancy and long-term pulmonary outcomes. J. Clin. Med., 6 (1), pii: E4

30. Siffel, C., Kistler, K.D., Lewis, J.F.M., \& Sarda, S.P. (2019). Global incidence of bronchopulmonary dysplasia among extremely preterm infants: a systematic literature review. $J$. Matern. Fetal Neonatal Med., 9, 1-11.

31. Committee on Fetus and Newborn. American Academy of Pediatrics and Canadian Paediatric Society. (2002). Postnatal cotricosteroids to treat or prevent chronic lung disease in preterm infants. Pediatrics, 109 (2), 330-338.

32. Nelin, L.D., \& Bhandari, V. (2017). How to decrease bronchopulmonary dysplasia in your neonatal intensive care unit today and "tomorrow". F1000Res., 6, 539.

33. Saugstad, O.D., Aune, D., Aguar, M., Kapadia, V., Finer, N., \& Vento, M. (2014). Systematic review and meta-analysis of optimal initial fraction of oxygen levels in the delivery room at $\leq 32$ weeks. Acta Paediatr., 103 (7), 744-751.

34. Oei, J.L., Vento, M., Rabi, Y., Wright, I., Finer, N., Rich, W., ..., \& Saugstad, O.D. (2017). Higher or lower oxygen for delivery room resuscitation of preterm infants below 28 completed weeks gestation: a metaanalysis. ADC Fetal Neonatal Ed., 102 (1), F24-F30.

35. Bubramaniam, P., Ho, J.J., \& Davis, P.G. (2016). Prophylactic nasal continuous positive airway pressure for preventing morbidity and mortality in very preterm infants. Cochrane Database Syst. Rev., 6, 1465-1858.

36. Fenton, T.R., \& Kim, J.H. (2013). A systematic review and meta-analysis to revise the fenton growth chart for preterm infants. BMC Pediatr., 13, 59

37. Li, Y.W., Yan, C.Y., Yang, L., \& Han, Z.L. (2017). Effect of breastfeeding versus formula milk feeding on preterm infants in the neonatal intensive care unit. Chin. J. Contemp. Pediatr., 19 (5), 572-575.

38. Mihatsch, W.A., Braegger, C., Bronsky, J., Cai, W., Campoy, C., Carnielli, V., ..., \& Yan, W. (2018). ESPGHAN/ESPEN/ ESPR/CSPEN guidelines on pediatric parenteral nutrition. Clin. Nutr., 37, (6 Pt B), 2303-2305.

39. Villar, J., Giuliani, F., Bhutta, Z., Bertino, E., Ohuma, E.O., Ismail, L.C., ..., \& Kennedy, S.H. (2015). Postnatal growth standards for preterm infants: the Preterm Postnatal Follow-up Study of the INTERGROWTH-21 ${ }^{\text {st }}$ Project. Lancet Glob. Health, 3(11), 681-691.

40. Rover, M.M., Viera, C.S., Silveira, R.C., Guimaraes, A.T., \& Grassiolli, S. (2016). Risk factors associated with growth failure in the follow-up of very low birth weight newborns. J. Pediatr. (Rio J.), 92, 307-313.

Отримано 12.05.20

Прийнято до друку 16.06.20

Електронна адреса для листування: pavlishin@tdmu.edu.ua 